\title{
DISTRIBUSI DAN PEMETAAN VARIAN-VARIAN \\ BAHASA JAWA \\ DI NUSA TENGGARA BARAT \\ (Suatu Kajian Dialektologi)
}

\section{Hartini $^{*}$}

\begin{abstract}
Abstrak
Penelitian ini bertujuan untuk memberikan informasi tentang bahasa Jawa beserta lokasinya di Provinsi Nusa Tenggara Barat serta mendeskripsikan tentang varian-varian yang terdapat dalam beberapa variabel linguistik dalam bahasa Jawa. Melalui metode dialektometri, dari 254 buah peta perbedaan unsur-unsur kebahasaan yang meliputi bidang fonologi dan leksikon, didapat tiga dialek dalam bahasa Jawa yang ada di Provinsi Nusa Tenggara barat, yaitu dialek Praya, Uma Sima, dan So Nggajah (DPUS), dialek Sakra (DSak) dan dialek Sepayung (DSep). Mengenai hubungan kekerabatan antardialeknya, dapat dikatakan bahwa DPUS lebih dekat dengan DSak daripada dengan DSep.
\end{abstract}

Kata Kunci:

\section{Pengantar}

Bahasa Jawa merupakan salah satu bahasa daerah yang mempunyai penutur cukup besar di Indonesia. Dalam rangka menyukseskan program Pemetaan Bahasa Nasional, bahasa Jawa yang terdapat di Provinsi Nusa Tenggara Barat (NTB) perlu disertakan karena telah diakui keberadaannya. Berdasarkan data dari Badan Pusat Statistik dan dari informasi beberapa orang penduduk setempat, dipilih lima daerah pengamatan yang dijadikan sebagai populasi sekaligus sebagai sampel penelitian ini, yaitu Desa/Kelurahan Praya di Lombok Tengah, Desa Sakra di Lombok Timur, Desa Sepayung dan Desa Uma Sima di Sumbawa, serta Desa So Nggajah di Dompu.

\footnotetext{
*) Sarjana Pendidikan, Pembantu Pimpinan pada Kantor Bahasa Prov. NTB
} 
Pemetaan bahasa di NTB cukup besar manfaatnya, baik dilihat dari bahasa-bahasa daerah yang ada di NTB maupun dilihat dari pembinaan dan pengembangan bahasa Nasional. Dari sudut bahasa yang ada di NTB, hasil kegiatan pemetaan bahasa di NTB ini merupakan salah satu keputusan Seminar Politik Bahasa Nasional, khususnya keputusan yang menyangkut pembinaan dan pengembangan bahasa daerah, dalam usaha menginventarisasi bahasa-bahasa yang ada di NTB.

Dari sudut pembinaan dan pengembangan bahasa Nasional, kegiatan pemetaan bahasa ini dapat digunakan untuk kepentingan pengenalan variasi penutur bahasa di NTB serta langkah-langkah yang perlu dilaksanakan dalam kebijaksanaan pembinaan bahasa Indonesia di NTB mengingat cukup banyaknya jumlah bahasa beserta wilayah dan penuturnya di daerah tersebut (Halim dalam Herusantosa, 1987).

Metode pengumpulan data yang digunakan dalam penelitian ini adalah metode cakap dengan teknik cakap semuka, teknik catat, dan teknik rekam (dengan melakukan wawancara). Instrumen yang digunakan adalah berupa daftar kosakata Swadesh sebanyak 200 buah dan kosakata Budaya Dasar sebanyak 880 buah, sedangkan metode analisis data yang digunakan adalah metode dialektometri dan berkas isoglos. Sementara untuk penentuan unsur-unsur bahasa yang berbeda, yaitu dengan menggunakan metode Padan Intralingual (PI) dengan Teknik Dasar Hubung Banding Intralingual (THBI) dan Teknik Lanjutan Hubung Banding (HB) Membedakan (HBB) atau dalam bentuk Tabulasi Data Tahap I dan Tahap II.

\subsection{Masalah Penelitian}

Berdasarkan uraian di atas, masalah yang ingin dijelaskan dalam penelitian ini adalah sebagai berikut. 
1. Di wilayah mana saja terdapat kantong-kantong bahasa Jawa di Provinsi Nusa Tenggara Barat?

2. Ada berapa varian bahasa pada tiap-tiap kantong bahasa Jawa di Provinsi Nusa Tenggara Barat?

3. Ada berapa jumlah penutur bahasa Jawa di tiap-tiap kantong bahasa Jawa di Provinsi Nusa Tenggara Barat?

4. Bagaimanakah hubungan kekerabatan tiap-tiap daerah kantong bahasa Jawa di Provinsi Nusa Tenggara Barat?

\subsection{Tujuan Penelitian}

Penelitian ini memiliki tujuan sebagai berikut.

1. Penelitian ini dapat memberikan informasi tentang bahasa Jawa beserta lokasinya di Provinsi Nusa Tenggara Barat.

2. Mendeskripsikan tentang varian yang terdapat dalam beberapa variabel linguistik dalam bahasa Jawa.

3. Mengetahui jumlah penutur bahasa Jawa di Provinsi Nusa Tenggara Barat serta sebaran geografisnya.

\section{Pembahasan}

Perbedaan linguistik yang dibicarakan dalam bagian ini mencakup bidang fonologi dan leksikon yang terdapat di antara daerahdaerah pengamatan. Berdasarkan data yang terkumpul telah teridentifikasi sebanyak 254 buah peta perbedaan unsur-unsur kebahasaan yang meliputi kedua bidang di atas dengan rincian 161 perbedaan fonologi yang meliputi 6 korespondensi vokal, 10 korespondensi konsonan, 62 variasi vokal, dan 83 variasi konsonan, sedangkan untuk perbedaan leksikon adalah sebanyak 93 buah perbedaan. Namun, untuk tulisan ini, hanya akan dipaparkan beberapa 
buah peta sebagai contoh. Patut ditambahkan bahwa peta yang ditampilkan sebagai contoh tersebut adalah peta yang dapat memberikan gambaran geografis dari varian-varian tersebut secara menyeluruh.

\subsection{Deskripsi Perbedaan Unsur-unsur Kebahasaan}

\subsubsection{Perbedaan Fonologi}

\subsubsection{Korespondensi Vokal}

Untuk korespondensi vokal akan dikemukakan semua contoh yang berhasil ditemukan yaitu sebanyak 6 buah korespondensi.

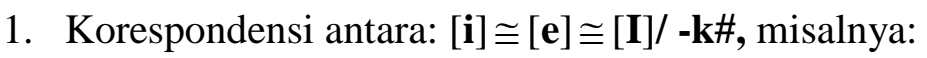

[ayin $] \cong[$ ayen $] \cong[$ ayIn] 'angin'

$[$ dagin $] \cong[$ dagen $] \cong[$ dhaghIn] 'daging'

$[$ kerin $] \cong[$ garen $] \cong[$ gharIn] 'kering'

[garin]

$[$ kulit $] \cong[$ kolet $] \cong[$ kullt $]$ 'kulit'

$[$ lanit $] \cong[$ layet $] \cong[$ lay It $]$ 'langit'

Daerah sebaran korespondensi ini adalah:

[i] pada daerah pengamatan 1,3 , dan 5

[e] pada daerah pengamatan 2

[I] pada daerah pengamatan 4. Selain itu, untuk makna-makna tersebut juga digunakan bentuk-bentuk: [maruto] dan [barat] 'angin' masing-masing pada daerah pengamatan 1 dan 3; [away-away] 'langit' pada daerah pengamatan 3 .

2. Korespondensi antara $[\mathbf{0}] \cong[\supset] /-\#$, misalnya:

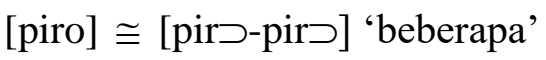

[limo] $\cong[\lim \supset]$ 'lima'

[ulo] $\cong[\mathrm{ul} \supset]$ 'ular' 
[oyo] $\cong[\mathrm{y}(\supset, \mathrm{u}) \mathrm{y} \supset]$ 'kencing'

Daerah sebaran korespondensi ini adalah:

[o] pada daerah pengamatan 1 .

[つ] pada daerah pengamatan 2, 3, 4, dan 5.

Selain itu, untuk makna-makna tersebut juga digunakan bentuk [pintən] 'beberapa' pada daerah pengamatan 1 .

3. Korespondensi antara $[\mathbf{u}] \cong[\mathbf{o}] \cong[\mathbf{U}] /$ /-k\#, misalnya:

$[(\mathrm{y}, \mathrm{k}) \mathrm{ukur}] \cong[$ kokor-kokor $] \cong[(\mathrm{k}, \mathrm{y}) \mathrm{ukUr}]$ 'garuk'

$[$ irup $] \cong[$ iron $] \cong[$ irUn] 'hidung'

$[(\mathrm{h}, \mathrm{y})$ ituy $] \cong[$ yetop $] \cong[$ yitUy] 'hitung'

$[\mathrm{d} ə \mathrm{kul}] \cong[\mathrm{də \eta} k \mathrm{kol}] \cong[\mathrm{dhə \eta} k \mathrm{kUl}]$ 'lutut'

$[$ sikut $] \cong[$ sekot $] \cong[$ sekUt $]$ 'siku', dll.

Daerah sebaran korespondensi ini adalah:

[u] pada daerah pengamatan 1 dan 5 .

[o] pada daerah pengamatan 2 .

[U] pada daerah pengamatan 3 dan 4 .

Selain itu, untuk makna-makna tersebut juga digunakan bentuk [juyur] 'hidung' pada daerah pengamatan 1.

\subsubsection{Korespondensi Konsonan}

Korespondensi konsonan dalam penelitian ini akan dikemukakan semua contoh data yang berhasil ditemukan, yaitu sebanyak 10 buah korespondensi.

1. Korespondensi antara $[\mathbf{b}] \cong[\mathbf{b h}] /$ \# -, misalnya:

[bapaq $] \cong[$ bhapaq] 'ayah'

$[$ bojo $] \cong[$ bhojo] 'istri'

$[\mathrm{b} \supset \mathrm{k} \supset \mathrm{y}] \cong[\mathrm{bh} \supset \mathrm{k} \supset \mathrm{y}]$ 'pantat' 


$$
\begin{aligned}
& {[\mathrm{b} \supset \mathrm{p} \supset \mathrm{y}] \cong[\mathrm{bh} \supset \mathrm{p} \supset \mathrm{q}] \text { 'bopong' }} \\
& {[\text { bujUq] } \cong[\text { bhujhUq] 'pantat' }}
\end{aligned}
$$

[bojoq]

Daerah sebaran korespondensi ini adalah:

[b] pada daerah pengamatan 1, 2, dan 5

[bh] pada daerah pengamatan 3 dan 4

Selain itu, untuk makna-makna tersebut juga digunakan bentuk [romo] 'ayah' pada daerah pengamatan 1.

2. Korespondensi antara $[\mathbf{b}] \cong[\mathbf{b h}] / \#-$, misalnya:

[baykEqan $] \cong[$ bhaykEqan] 'pinggang'

$[\mathrm{b} \supset \mathrm{k} \supset \mathrm{y}] \cong[\mathrm{bh} \supset \mathrm{k} \supset \mathrm{y}]$ 'pinggul'

[biy $(\mathrm{e}, \mathrm{E}) \mathrm{n}] \cong[\mathrm{bh}(\partial, \mathrm{i})$ yen $]$ 'dahulu'

Daerah sebaran korespondensi ini adalah:

[b] pada daerah pengamatan 1 dan 5 .

[bh] pada daerah pengamatan 3 dan 4 .

Selain itu, untuk makna-makna tersebut juga digunakan bentuk

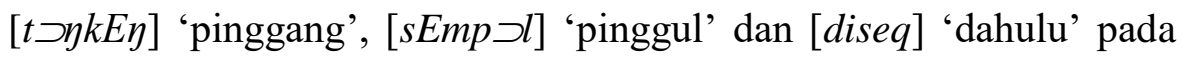
daerah pengamatan 2 .

3. Korespondensi antara $[\mathbf{h}] \cong[\boldsymbol{\emptyset}] /$ - \#, misalnya:

$[\operatorname{gət}(\mathrm{i}, \mathrm{E}) \mathrm{h}] \cong[$ gəte] 'darah'

[ghitte]

[uyah] $\cong[$ uya] 'garam'

[lə⿹gah $] \cong[$ longo] 'duduk'

[lungUh]

Daerah sebaran korespondensi ini adalah: 
[h] pada daerah pengamatan 1 dan 5 .

[Ø] pada daerah pengamatan 3 dan 4.

Selain itu, untuk makna-makna tersebut juga digunakan bentuk [ $\mathrm{rah}]$ 'darah' dan [jag $\supset$ ]] 'duduk' pada daerah pengamatan 1 .

\subsubsection{Variasi Vokal}

Perbedaan yang berupa variasi vokal yang ditemukan dalam penelitian ini adalah sebagai berikut:

1. Variasi vokal $[\mathbf{a}] \sim[\boldsymbol{\varnothing}] / \#-$, misalnya:

[añar] [ñar] 'baru'

[a] digunakan pada daerah pengamatan 1,3,4, dan 5 .

[Ø] digunakan pada daerah pengamatan 2 .

2. Variasi vokal $[\mathbf{e}] \sim[\mathbf{E}] \sim[\mathbf{i}] /$ - \#, misalnya:

[gəde] $\sim$ [gədhE] [ghədhi]'besar'

[gEdE]

[e] digunakan pada daerah pengamatan 1 dan 2 .

[E] digunakan pada daerah pengamatan 3 dan 5.

[i] digunakan pada daerah pengamatan 4

3. Variasi vokal $[\mathbf{i}] \sim[\mathbf{I}] \sim[\mathbf{E}] /$ \#(k)-, misalnya:

[(b,1)intay $] \sim[$ lIntay $] \sim$ [Entay] 'bintang'

[i] digunakan pada daerah pengamatan 1, 3, dan 5 .

[I] digunakan pada daerah pengamatan 4 .

[E] digunakan pada daerah pengamatan 2 .

4. Variasi vokal $[\mathbf{i}] \sim[\emptyset] /$ - \#, misalnya:

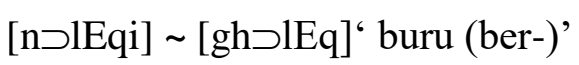


[i] digunakan pada daerah pengamatan 2 .

[Ø] digunakan pada daerah pengamatan 3 dan 4 .

selain bentuk-bentuk di atas, makna tersebut juga direalisasikan dengan menggunakan bentuk [buru] yang digunakan pada daerah pengamatan 1 dan 5 .

\subsubsection{Variasi Konsonan}

Perbedaan yang berupa variasi vokal yang ditemukan dalam penelitian ini adalah sebagai berikut.

1. Variasi konsonan $[\mathbf{w}] \sim[\mathbf{b}] / \mathbf{v}-\mathbf{v}$, misalnya:

$[\mathrm{awu}] \sim[\mathrm{abu}]$ 'abu'

[w] digunakan pada daerah pengamatan: 1, 2, 3, dan 4 .

[b] digunakan pada daerah pengamatan 5 .

2. Variasi konsonan $[\mathbf{n n}] \sim[\mathbf{n}] / \mathbf{v}-\mathbf{v}$, misalnya:

[g(h)ənni] [gəni] 'api'

[nn] digunakan pada daerah pengamatan 1 dan 4 .

[n] digunakan pada daerah pengamatan 2, 3, dan 5 .

selain bentuk-bentuk di atas, makna tersebut juga direalisasikan dengan menggunakan bentuk [gəromo] yang digunakan pada daerah pengamatan 1 .

3. Variasi konsonan $[\mathbf{y}] \sim[\mathbf{k}] / \#$ - , misalnya:

[yambay] [k(om)ambay] 'apung(me-)'

[y] digunakan pada daerah pengamatan 1, 3, dan 4

[k] digunakan pada daerah pengamatan 2 dan 4

selain bentuk-bentuk di atas, makna tersebut juga direalisasikan dengan menggunakan bentuk [yapuy] yang digunakan pada daerah pengamatan 5 . 
4. Variasi konsonan $[\mathbf{p p}] \sim[\mathbf{p}] \sim[\mathbf{p r}] / \#(\mathbf{k v})-$, misalnya:

[kəppiye] [kəpiye] [kəpriye] 'bagaimana'

[piyE]

[pp] digunakan pada daerah pengamatan 1 .

[p] digunakan pada daerah pengamatan 3 dan 4.

[pr] digunakan pada daerah pengamatan 3 dan 5.

selain bentuk-bentuk di atas, makna tersebut juga direalisasikan dengan menggunakan bentuk [kadus pundi] yang digunakan pada daerah pengamatan: 1 ; bentuk $[y \supset q \neg p \supset]$ yang digunakan pada daerah pengamatan 2 dan 4 .

\subsubsection{Perbedaan Leksikon}

Berdasarkan data yang diperoleh dari penelitian, ternyata perbedaan linguistik cukup banyak ditemukan dalam bidang leksikon, di samping perbedaan fonologi serta daerah sebarannya sangat beragam. Namun demikian, dalam bagian ini tidak akan dikemukakan semua perbedaan itu secara satu per satu melainkan hanya sebagian saja, yang diharapkan dapat memberikan gambaran daerah sebaran perbedaan-perbedaan tersebut secara menyeluruh. Perlu dikemukakan pula bahwa semua perbedaan leksikon itu berwujud perbedaan yang berupa variasi.

Sehubungan itu, akan dikemukakan beberapa perbedaan leksikon yang dimaksud seperti di bawah ini.

1. Makna 'air' memunculkan dua varian, yaitu bañu yang digunakan pada daerah pengamatan: 1-5; dan tirto yang digunakan pada daerah pengamatan 1 .

2. Makna 'anak' memunculkan dua varian, yaitu anaq yang digunakan pada daerah pengamatan 1-5; dan larE yang digunakan pada daerah pengamatan 4 . 
3. Makna 'alir(me-)' memunculkan dua varian, yaitu mili yang digunakan pada daerah pengamatan 1-4; dan yalir yang digunakan pada daerah pengamatan 5 .

4.. Makna 'asap' memunculkan empat varian, yaitu: as (o,a)p yang digunakan pada daerah pengamatan 1 dan 3; bIloq, bhallUq yang digunakan pada daerah pengamatan 2 dan 4; kokos yang digunakan pada daerah pengamatan 4; dan tzluh yang digunakan pada daerah pengamatan 5 .

5. Makna 'awan' memunculkan empat varian, yaitu: $m ə n d(u, U) \eta$ yang digunakan pada daerah pengamatan 1 dan 3; awan yang digunakan pada daerah pengamatan $1 ; m E g \supset$ yang digunakan pada daerah pengamatan 2 dan 4; dan slun yang digunakan pada daerah pengamatan 5 .

\subsection{Penentuan Status Isolek}

Dalam bagian ini akan dilakukan penentuan isolek sebagai dialek atau subdialek. Hal ini dimaksudkan agar diperoleh gambaran yang jelas mengenai hubungan yang terdapat antara isolek yang digunakan pada setiap daerah pengamatan. Untuk mencapai tujuan tersebut, upaya yang dilakukan adalah menghitung secara kuantitatif, yaitu dengan metode dialektometri dan menghitung jumlah isoglos yang berfungsi menyatukan daerah-daerah pengamatan, yang menampilkan gejala kebahasaan yang serupa.

Dengan kata lain, jumlah isoglos yang menyatukan daerah-daerah pengamatan yang menampilkan gejala-gejala kebahasaan yang serupa itu dijadikan landasan dalam menentukan isolek sebagai dialek atau subdialek. Dengan demikian, dalam menentukan status isolek sebagai 
dialek atau subdialek tidak hanya dilakukan secara kuantitatif tetapi juga secara kualitatif yaitu melalui inovasi bersama.

Dengan berpijak pada patokan-patokan yang ditentukan dalam metode penentuan dialek/ subdialek, dapatlah dikatakan bahwa bahasa Jawa di Nusa Tenggara Barat memiliki tiga dialek, yaitu:

1. Dialek Praya, Uma Sima, dan So Nggajah (DPUS) yang mencakup daerah pengamatan 1, 3, dan 5;

2. Dialek Sakra (DSak) yang mencakup daerah pengamatan 2, dan

3. Dialek Sepayung (DSep) yang mencakup daerah pengamatan 4.

Secara kuantitatif, hasil pembagian dialek tersebut dapat dilihat dari tabel hasil penghitungan dialektometri dengan cara permutasi antardaerah pengamatan atau dengan cara membandingkan pada setiap daerah pengamatan berikut ini.

\section{Hasil Penghitungan Dialektometri}

\begin{tabular}{|c|c|c|}
\hline $\begin{array}{c}\text { Daerah Pengamatan } \\
\text { yang Diperbandingkan }\end{array}$ & Persentase & Keterangan \\
\hline $1-2$ & $67 \%$ & Beda Dialek \\
\hline $1-3$ & $51 \%$ & Beda Dialek \\
\hline $1-4$ & $58 \%$ & Beda Dialek \\
\hline $1-5$ & $40 \%$ & Subdialek \\
\hline $2-3$ & $73 \%$ & Beda Dialek \\
\hline $2-4$ & $70 \%$ & Beda Dialek \\
\hline $2-5$ & $68 \%$ & Beda Dialek \\
\hline $3-4$ & $38 \%$ & Subdialek \\
\hline $3-5$ & $46 \%$ & Subdialek \\
\hline $4-5$ & $53 \%$ & Beda Dialek \\
\hline
\end{tabular}

Berdasarkan penghitungan di atas, jelas bahwa bahasa Jawa di Nusa Tenggara Barat memiliki tiga dialek, yaitu yang mencakup daerah pengamatan 1, 3, dan 5; daerah pengamatan 2; dan daerah pengamatan 4 . Hal tersebut dapat dilihat dari perbandingan antara daerah pengamatan 1 dan 2 yang menganggap bahwa kedua daerah pengamatan tersebut adalah 
beda dialek dengan tingkat kekerabatan sebesar $67 \%$. Kemudian, jika dilihat dari persentasenya, daerah pengamatan 1 juga menganggap bahwa daerah pengamatan 3 adalah beda dialek dengan tingkat kekerabatan sebesar $51 \%$. Namun, antara daerah pengamatan 1 dan 5 serta antara daerah pengamatan 3 dan 5 termasuk ke dalam subdialek dengan tingkat kekerabatan masing-masing sebesar $40 \%$ dan $46 \%$. Dengan demikian, dari uraian di atas dapat diartikan bahwa antara daerah pengamatan 1, 3, dan 5 merupakan satu dialek.

Di sisi lain, meskipun daerah pengamatan 3 menganggap bahwa daerah pengamatan 4 merupakan subdialek atau termasuk ke dalam satu dialek dengan daerah 1, 3, dan 5 dengan tingkat kekerabatan sebesar $38 \%$, tetapi jika dibandingkan daerah pengamatan 1 dan 5 menolaknya. Hal tersebut dapat dilihat dari perbandingan antara daerah pengamatan 1 dan 4; 4 dan 5. Daerah Pengamatan 1 menganggap bahwa daerah 4 adalah beda dialek, dengan tingkat kekerabatan sebesar 58\%, begitu pula dengan perbandingan antara daerah pengamatan 4 dan 5 yang juga menganggap beda dialek dengan tingkat kekerabatan sebesar 53\%. Dengan demikian, dapat diartikan bahwa daerah pengamatan 4 adalah dialek tersendiri.

Selanjutnya, antara daerah pengamatan 2 dan 3, termasuk ke dalam beda dialek dengan tingkat kekerabatan yang cukup tinggi, yaitu sebesar 73\%. Begitu pula daerah pengamatan 2 juga menganggap daerah 4 adalah beda dialek dengan tingkat kekerabatan sebesar 70\%, sedangkan antara daerah pengamatan 2 dengan daerah pengamatan 5 juga beda dialek dengan tingkat kekerabatan sebesar 68\%. Itu artinya, khusus daerah pengamatan 2 merupakan dialek tersendiri karena tidak ada satu daerah pun yang menganggapnya sebagai satu dialek. 
Selain dengan metode dialektometri, penghitungan dalam penentuan status isolek apakah sebagai dialek atau subdialek juga dilakukan dengan metode berkas isoglos. Isoglos yang mempersatukan daerah-daerah dialek di atas dapat dijelaskan sebagai berikut. Untuk dialek Praya, Uma Sima, dan So Nggajah (DPUS) yang mencakup daerah pengamatan 1 , 3, dan 5, dari 254 peta yang diperbandingkan terdapat 29 buah isoglos yang menyatukan daerah-daerah pengamatan dalam dialek ini dan sekaligus membedakannya dengan daerah pengamatan lainnya yang tidak sedialek dengannya. Dari 29 buah peta tersebut terdapat 16 buah isoglos yang berupa korespondensi. Meskipun dalam penghitungan persentase melalui metode berkas isoglos ini hanya mencapai $11,41 \%$ dan termasuk perbedaan wicara, namun secara kualitatif melalui inovasi bersama daerah 1,3 , dan 5 tetap dinyatakan pada satu dialek. Dalam hal ini, data korespondensilah yang sangat memperkuat dalam penyatuan daerah-daerah pengamatan tersebut, seperti dalam contoh korespondensi vokal $[\mathrm{i}] \cong[\mathrm{e}] \cong[\mathrm{I}] / \mathrm{-k \#}$ yang terdapat dalam bentuk:

[ajin $] \cong[$ ayen $] \cong[$ ayIn] 'angin'

$[$ dagin $] \cong[$ dagen $] \cong[$ dhaghIn] 'daging'

$[$ kerin $] \cong[$ garen $] \cong[$ gharIn] 'kering'

[garin]

$[$ dagin $] \cong[$ dagen $] \cong[$ dhaghI $]$ 'daging'

[kulit $] \cong[$ kolet $] \cong[$ kullt $]$ 'kulit'

[lanit $] \cong[$ layet $] \cong[$ layIt] 'langit', dll.

Daerah sebaran korespondensi ini adalah:

[i] pada daerah pengamatan: $1,3,5$

[e] pada daerah pengamatan: 2 dan

[I] pada daerah pengamatan: 4 . 
Selain 6 buah isoglos korespondensi vokal seperti yang telah disebutkan di atas, masih ada 7 buah isoglos lain yang menggunakan kaidah yang sama hingga keseluruhan data isoglos korespondensi vokal dengan kaidah ini sebanyak 13 buah isoglos yaitu isoglos yang mempunyai makna 'pohon', 'telinga', 'lirik', 'tulis', 'berak', 'ingat', dan 'intai', sementara itu, terdapat pula 6 buah isoglos variasi serta 7 buah isoglos leksikon yang menyatukan daerah 1, 3, dan 5 ini.

Selanjutnya, untuk dialek Sakra (DSak) yang terdapat pada daerah pengamatan 2, terdapat 142 buah isoglos yang terdiri atas 43 buah isoglos yang berupa korespondensi, 58 buah isoglos yang berupa variasi, dan 41 buah isoglos yang berupa leksikon dari 254 buah peta yang diperbandingkan. Itu artinya, terdapat sebanyak 55,9 \% yang membedakan daerah pengamatan yang masuk dalam dialek ini dengan daerah-daerah pengamatan lainnya.

Adapun yang menyatukan daerah pengamatan dialek Sepayung (DSep) yaitu pada daerah pengamatan 4 adalah sebanyak 66 buah isoglos. Itu artinya, terdapat 25,98 \% yang membedakan daerah pengamatan yang menjadi wilayah pakai dialek ini dengan daerah pengamatan lainnya. Namun demikian, pada daerah pengamatan ini terdapat 17 buah isoglos yang berupa korespondensi. Hal tersebutlah yang dapat memperkuat data kuantitatif bahwa daerah pengamatan 4 memiliki dialek tersendiri. Di samping isoglos-isoglos yang berupa korespondensi, terdapat pula 33 buah isoglos yang berupa variasi dan 16 buah isoglos yang berupa leksikon. 
Berikut ini adalah peta dialek bahasa Jawa di NTB, sebagai berikut:

¿??????????????????????????????

\subsection{Penentuan Hubungan Kekerabatan Antardialek}

Dari uraian tersebut di atas telah didapat tiga dialek bahasa Jawa di NTB, yaitu dialek Praya, Uma Sima, dan So Nggajah (DPUS), dialek Sakra (DSak) lalu dialek Sepayung (DSep) yang dapat dilihat dalam bagan berikut ini.

\section{Bahasa Jawa di NTB}

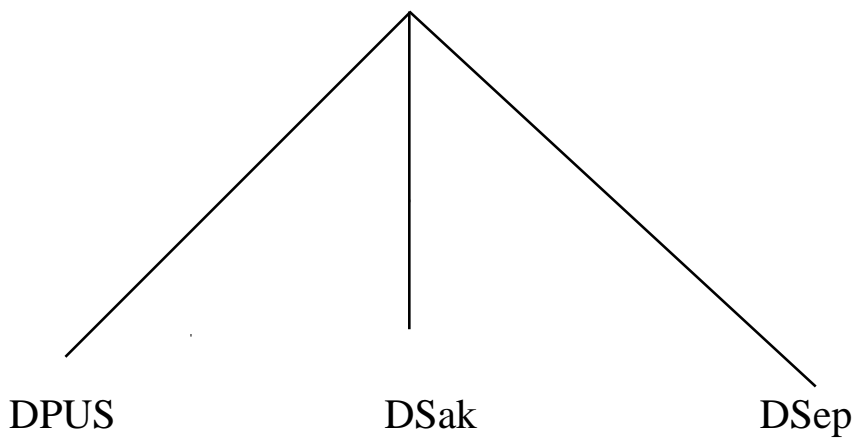

Selanjutnya, dari tiga dialek tersebut dapat ditentukan hubungan kekerabatannya dengan cara melihat persentase yang terkecil. Semakin kecil persentasenya, semakin dekat hubungan antardialek yang satu dengan dialek yang lainnya. Pada DPUS yang mencakup daerah pengamatan 1, 3, dan 5, jika dibandingkan DSak yang meliputi daerah pengamatan 2, maka akan dilihat jumlah persentase dari perbandingan antara daerah 1 dan 2, 3 dan 2 serta 5 dan 2, yaitu $(67 \%+73 \%+68 \%)$ : 3 , persentase yang dihasilkan sebesar $69 \%$. 
Apabila dibandingkan lagi antara daerah pengamatan 2 dan 4 , yaitu sebesar $\quad 70 \%$. Dengan demikian, DPUS lebih dekat dengan DSak daripada dengan DSep. Oleh karena itu, dalam pohon kekerabatan DPUS dan DSak berada dalam satu payung DPUSSak seperti dapat dilihat dalam bagan pohon kekerabatan berikut ini.

Bahasa Jawa di NTB

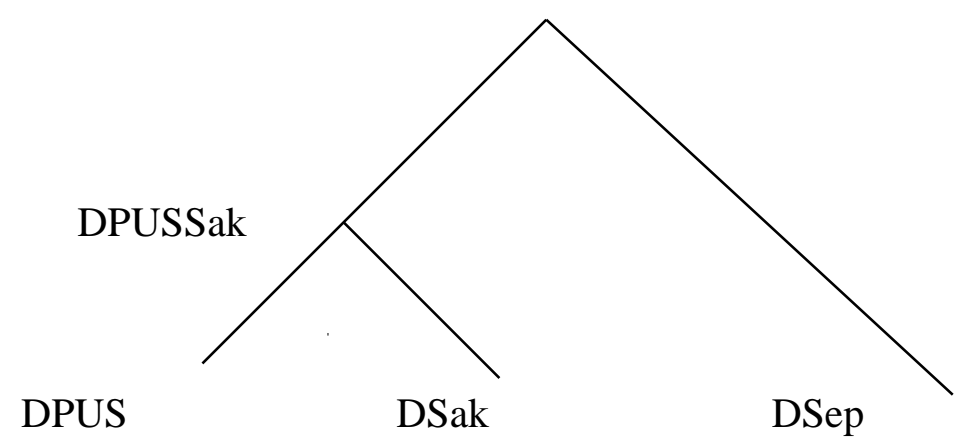

\section{Penutup}

\subsection{Simpulan}

Dari uraian di atas dapat dikemukakan beberapa hal sebagai kesimpulan berikut ini. Berdasarkan data yang terkumpul telah teridentifikasi sebanyak 254 buah peta perbedaan unsur-unsur kebahasaan yang meliputi perbedaan fonologi dan leksikon. Dalam hal ini, perbedaan fonologi yang berjumlah 161 buah peta terdiri atas 6 korespondensi vokal, 10 korespondensi konsonan, 62 variasi vokal, dan 83 variasi konsonan, sedangkan untuk perbedaan leksikon adalah sebanyak 93 buah perbedaan. 
Selanjutnya, dengan menggunakan metode dialektometri dari 254 buah peta yang diperbandingkan, didapat tiga dialek bahasa Jawa yang ada di NTB. Tiga dialek tersebut adalah sebagai berikut.

1. Dialek Praya, Uma Sima, dan So Nggajah (DPUS) yang mencakup daerah pengamatan 1,3 , dan 5 ;

2. Dialek Sakra (DSak) yang mencakup daerah pengamatan 2, dan

3. Dialek Sepayung (DSep) yang mencakup daerah pengamatan 4.

Sementara itu, jika dilihat dari hubungan kekerabatan antardialeknya, jarak antara DPUS dengan DSak adalah sebesar 69\%, sedangkan jarak antara DSak dengan DSep adalah sebesar 70\%. Meskipun perbedaan antardialek tersebut hanya sebesar $1 \%$, tetapi dapat dikatakan bahwa DPUS lebih dekat dengan DSak daripada dengan DSep.

\subsection{Saran}

1. Untuk memperoleh hasil penelitian yang lebih akurat, perlu dilakukan survei lokasi terlebih dahulu dan sedikit melakukan wawancara secara umum kepada kepala desa atau penduduk setempat mengenai situasi kebahasaan yang ada di desa tersebut.

2. Perlu diteliti lebih lanjut mengenai kemungkinan-kemungkinan kontak bahasa yang terjadi antara bahasa Jawa yang berkembang sebagai minoritas dengan bahasa-bahasa lain yang berada di sekitarnya sebagai bahasa mayoritas. 


\section{DAFTAR PUSTAKA}

Bawa, I Wayan. 1983. Bahasa Bali di Bali: Sebuah Analisis Geografi Dialek".Jakarta: Universitas Indonesia (Disertasi Doktor).

Blust, Robert A. 1970. "Proto-Austronesian Addenda". Oceanic Linguistics. IX/2: 104-162.

Bynon, T. 1979. Historical Linguistics. Cambridge: University Press.

Dyen, Isidore. 1971. "The Austronesian Languages and ProtoAustronesian". Current Trends in Linguistics 8: 5-54.

Esser, S.J. 1938. Atlas van Tropisch Nederland. Batavia Centrum.

Herusantoso, Suparman, dkk. 1987. Pemetaan Bahasa-Bahasa di Nusa Tenggara Barat. Jakarta: Pusat Pembinaan dan Pengembangan Bahasa. Koentjaraningrat. 1984. Kebudayaan Jawa. Jakarta: Balai Pustaka.

Kridalaksana, Harimurti. 1984. Kamus Linguistik. Jakarta: PT Gramedia.

Lauder, Multamia RMT. 1984. "Usaha melacak Bahasa-Bahasa Nusantara". Makalah dalam Pertemuan Linguistik Bahasa dan Budaya Atmajaya (PELBBA 12). Jakarta:

Mahsun. 1994. "Penelitian Dialek Geografis Bahasa Sumbawa". Yogyakarta: Universitas Gadjah Mada (Disertasi Doktor).

Mahsun. 1995. Dialektologi Diakronis: Sebuah Pengantar. Yogyakarta: Gadjah Mada University Press.

Mahsun. 1997. "Linguistik Diakronis dan Pengembangan Materi Muatan Lokal Bahasa Daerah yang Berwawasan Kebangsaan”. Makalah 
pada Seminar Internasional Bahasa dan Budaya di Dunia Melayu, di Universitas Mataram, Juli 1997.

Mahsun. 1998. "Pengembangan Materi Muatan Lokal yang Berdimensi Kebhinnekatunggalikaan dan Pengajarannya: Penyusunan Bahan Pelajaran Bahasa Sasak dengan Memanfaatkan Variasi Bahasa yang Berkerabat". Laporan Riset Unggulan Terpadu Tahun I, 1998. Dewan Riset Nasional: Jakarta.

Mbete, Aron Meko. 1990. "Rekonstruksi Protobahasa Bali-SasakSumbawa'. Jakarta: Universitas Indonesia (Disertasi Doktor).

Nothofer, Bernd. 1975. The Reconstruction of Proto-Malayo-Javanic. S'Gravenhage-Martinus Nijhoff.

Nothofer, Bernd. 1981. Dialekktatlas von Zentral-Java. Wiesbaden: Otto Harrassowitz.

Poedjasoedarma, Soepomo. 1979. Tingkat tutur Bahasa Jawa. Jakarta: Pusat Pembinaan dan Pengembangan Bahasa.

Poerwadarminta, W.J.S. 1939. Baoesastra Djawa. Groningen, Batavia: J.B. Wilters' Uitgevers Maat Schapij N.V.

Sukartha, I Nengah dkk. 1987. "Geografi Dialek Bahasa Sumbawa di Pulau Sumbawa". Denpasar: Laporan Penelitian Bahasa dan Sastra Indonesia dan Daerah Bali.

Tawangsih Lauder, Multamia R.M. 1990. "Pemetaan dan Distribusi Bahasa-bahasa di Tangerang". Disertasi Doktor. Jakarta: Universitas Indonesia.

Teeuw, A. 1958. Lombok: Een Dialect Geogrfische Studie. S'Gravenhage: Martinus Nijhoff

Wacana, H.L. 1988. Sejarah Daerah Nusa Tenggara Barat. Proyek Inventarisasi dan Dokumentasi Kebudayaan Nusa Tenggara Barat.

Wurm, S.A. and S. Hattori. 1983. "Map of Insular Southeast Asia. II". Pacifics Linguistics. C.76. 
Mabasan - Vol. 2 No. 2 Juli-Desember 2008 